\title{
Genetic machinery for RNA silencing and defense against viruses in Citrus
}

\author{
Vagner Augusto Benedito ${ }^{1}$, Laura Faria ${ }^{2}$, Juliana Freitas-Astúa ${ }^{2,3}$ and Antonio Figueira ${ }^{1}$ \\ ${ }^{1}$ Centro de Energia Nuclear na Agricultura, Universidade de São Paulo, Piracicaba, SP, Brazil. \\ ${ }^{2}$ Centro APTA Citros Sylvio Moreira, Instituto Agronômico de Campinas, Cordeirópolis, SP, Brazil. \\ ${ }^{3}$ Embrapa Mandioca e Fruticultura Tropical, Cruz das Almas, BA, Brazil.
}

\begin{abstract}
RNA silencing mechanisms are conserved throughout eukaryotic evolution, possibly due to their importance in viral resistance and other aspects of cell biology. Here, we explored the Citrus EST (CitEST) database in search of sequences related to the most important known genes involved in RNA silencing. Transcripts strongly matching Argonaute $(A G O)$, Dicer-like $(D C L)$, Hua enhancer $(H E N)$, and RNA-dependent RNA Polymerase $(R d R P)$ were found in many of the citrus libraries. The reads were clustered and quantified. This shows that post-transcriptional gene silencing apparatus is active in citrus. It seems plausible that a better understanding of the players of RNA silencing in Citrus spp. and related genera may help create new tools to defeat the viral diseases that affect the citrus industry. Functional analyses of these citrus genes would enable the pursuit of this hypothesis.
\end{abstract}

Key words: CitEST, Gene silencing, PTGS.

Received: July 24, 2006; Accepted: February 8, 2007.

RNA silencing is a ubiquitous and highly conserved phenomenon throughout the evolution of eukaryotes (Mette et al., 2000; Baulcombe, 2004). It plays a role in cellular defense against viruses (Waterhouse et al., 2001) and transposons (Bennetzen, 2000), as well as in chromatin remodeling (Chandler and Vaucheret, 2001) and developmental regulation (Kidner and Martienssen, 2005). Three major mechanisms are recognized by which RNA can be silenced in plant cells: i) Post-Transcriptional Gene Silencing (PTGS) mediated by small interfering RNAs (siRNAs); ii) microRNAs (miRNAs) that finely regulate gene expression through mRNA degradation or translation arrest; and iii) Transcriptional Gene Silencing (TGS), which drives chromatin remodeling (via DNA and histone methylation) also through siRNAs (Baulcombe, 2004; Qi and Hannon, 2005). The trans-acting siRNA (tasiRNAs) pathway couples two of these mechanisms: a miRNA targeting an intermediate transcript (tasiRNA) that will produce siRNAs to silence target genes (Vazquez et al., 2004). These processes are related and collectively called RNA silencing. They depend upon cellular recognition of double-stranded RNAs (dsRNAs), originated, for example, during virus replication, hairpin RNA or miRNA annealing to a complementary RNA transcript. Detection of dsRNA by cells will elicit

Send corespondence to Juliana Freitas-Astúa. Centro APTA Citros Sylvio Moreira, Instituto Agronômico de Campinas, Rod. Anhanguera km 158, 13490-970, Cordeirópolis, SP, Brazil. E-mail: jfastua@centrodecitricultura.br. the appropriate machinery to degrade any transcripts similar to those found as dsRNA.

The current model of PTGS establishes that once a dsRNA is recognized by the cell, an enzyme called Dicer (coded by four DCL genes in Arabidopsis) cuts it into 21-23 nt (siRNAs) sections. These fragments are recognized by the so-called RNA-Induced Silencing Complex (RISC), which plays a surveillance role in finding similar transcripts matching one strand of the fragmented RNA, followed by cutting them down or, alternatively, by allowing an RNA-dependent RNA Polymerase (RdRP) to use these siRNAs as primers for extending the cognate transcript, generating new dsRNA that, in turn, will be recognized by Dicer, restoring the cycle in a reiterated process (Benedito et al., 2004). Translation arrest of target transcripts can also occur through this mechanism. Some virus genomes contain genes to counter-attack, called Silencing-Suppressors, which are involved in avoiding silencing mechanisms through strategies, such as hindrance of the RISC assembling or targeting, and avoidance of systemic spreading of silencing signals (Qu and Morris, 2005).

The CitEST database, with 242,790 Expressed Sequence Tags (ESTs), is derived from 33 libraries of eight Citrus and one Poncirus species (Targon et al., this issue), and represents a valuable platform for analyzing the genetic machinery involved in RNA silencing in citrus species. Identifying RNA silencing will allow a more accurate analysis of these mechanisms, helping to unravel evolutionary aspects. Moreover, mechanisms of gene silencing or silenc- 
ing suppression may be used in citrus molecular breeding, since Citrus tristeza virus (CTV; Closterovirus), the most important virus of citrus orchards worldwide, holds three distinct silencing suppressors in its $\sim 20-\mathrm{kb}$ genome ( $\mathrm{Lu}$ et al., 2004). Suppression of endogenous RNA silencing machinery in host cells by multiple mechanisms may represent the basis for virulence and infectivity success. Thus, tackling CTV RNA silencing suppressors may also help to elucidate and identify possible mechanisms of resistance.

In plants, RNA silencing is better understood in model species, such as Arabidopsis thaliana, than in crops, and even less in perennial species, such as Citrus spp. Some aspects of PTGS have, nevertheless, been investigated in a few woody species, such as Eucalyptus (Sassaki et al., 2005), plum (Scorza et al., 2001; Hily et al., 2005) and Citrus (Domínguez et al., 2002; Lu et al., 2004; Fagoaga et al., 2006). The CTV coat protein gene $p 25$ was shown to be silenced under non-selective conditions in a transgenic Mexican lime (Citrus aurantifolia) (Domínguez et al., 2002), indicating that the silencing surveillance system is active in this species. More recently, PTGS of the CTV silencing suppressor $p 23$ was revealed to confer CTV resistance in Mexican lime (Fagoaga et al., 2006), implying how useful this system can be for molecular breeding in order to overcome one of the greatest constraints of the citrus industry worldwide.

This work explored the CitEST database to find genes involved in RNA silencing; transcriptional profiles of Citrus and Poncirus species were contrasted to establish principles to further functionally investigate this mechanism in citrus. Searches to identify genes that putatively code for proteins known to participate in RNA silencing were carried out using the CitEST database from the Citrus Biotechnology Laboratory at the Instituto Agronômico de Campinas (IAC), Brazil. For this study, 29 libraries encompassing 162,902 reads were used. Searches were performed by tBLASTx using as query protein sequences already characterized and an $\mathrm{E}_{\text {value }}<10^{-10}$ as threshold. Reads were scrutinized individually and clustered using the CAP3 software (Huang and Madan, 1999) with default parameters such as an overlap length cutoff of 40 and an overlap length identity cutoff of $80 \%$. Reads composing each tentative consensus (TC) were quantified in selected CitEST libraries and grouped by species and tissues. Since each library presented a different number of reads, the results were normalized to 10,000 reads. Information on construction of the libraries can be found at Targon et aI. (this issue).

We found significant matches in the CitEST database for Argonaute (AGO), Dicer-like (DCL), Hua Enhancer $(H E N)$, and the RNA-dependent RNA Polymerase Suppressor of Gene Silencing (SGS3). No significant matches were found for $S D E 2$, SDE3, SDE4, SGS1 or SGS2. Quantification of reads assembled into TCs of selected tissues and species can be viewed in Tables 1 and 2, respectively. Table 3 displays sequence similarities among the most abundant citrus TCs and their putative orthologues in Arabidopsis.

ARGONAUTE is a family of RNA binding proteins, with a conserved PAZ domain which is implicated in cleaving target RNA through the RNA-induced silencing complex (RISC; Baumberger and Baulcombe, 2005). There are 10 AGO paralogues in Arabidopsis (Carmell et al., 2002; Morel et al., 2002), and so far, some have been associated with distinct pathways of gene silencing. AGO1 appeared to act with miRNA (Fagard et al., 2000; Vaucheret et al., 2004), whilst AGO4 acted on epigenetic silencing (Zilberman et al., 2003, 2004), and AGO7 and AGO10 on developmental processes (Moussian et al., 1998; Lynn et al., 1999; Hunter et al., 2003). We identified 129 reads significantly similar to Arabidopsis $A G O$ paralogues that were grouped into 13 TCs and 18 singlets. Transcriptional modulation of $A G O$ TCs within species and tissues was noted. TC1-4 was more actively transcribed than the other clusters; however, detention of differential transcription in tissues or species was limited by the relatively low number of reads in some libraries. It is interesting to note, though, that leaves showed higher expressions of $\mathrm{TC} 1$ and TC4, whereas TC2 was the most active in fruit tissues.

Twenty-five transcripts with high similarity to Dicer-like proteins (DCL1-4) in the Arabidopsis genome (Gasciolli et al., 2005) were grouped into three TCs and seven singlets. A more accurate quantification of gene expression of putative $D C L$ paralogues in citrus is required to understand transcriptional modulation in tissues, and environmental and developmental conditions within species, but since the Dicer enzyme is a critical component in RNA silencing mechanisms, this study might raise some special features critical for viral defense.

In Arabidopsis, HEN was shown to play a role in development (Chen et al., 2002) and virus resistance (Mourrain et al., 2000, 2002). Recently, HEN1 was biochemically characterized and revealed to methylate duplexes of miRNAs or siRNAs to prepare primers for RdRP sequence extension for the following cycle of gene silencing (Yang et al., 2006). Only 14 reads similar to the Arabidopsis HEN were retrieved from the CitEST database, corresponding to five TCs and one singlet. Two TCs were formed only by reads from $C$. sinensis (TC1 and 4). Some less represented libraries of specific tissues (such as root, flower and seed) did not show any transcription of $H E N$-related RNA, neither did libraries of some species such as $C$. aurantifolia, $C$. limonia, and C. latifolia. Analysis of transcriptional modulation of $H E N$-related sequences seemed to be limited due to the small number of reads found in the CitEST database.

Host RdRPs are thought to act as sensors of foreign RNA, turning them into dsRNAs to enter the silencing pathway (Zamore, 2002). Forty-four reads matching the Arabidopsis RNA-dependent RNA polymerase SGS2/ SDE1/RDR6 were retrieved from the CitEST database and they formed six TCs and six singlets. TC1 returned 25 
Table 1 - Abundance of reads grouped into tentative consensi (TC) of genes involved in RNA silencing pathways per tissue in selected libraries from the CitEST database ${ }^{\mathrm{a}}$. Frequency is given per 10,000 transcripts and absolute numbers of valid reads are shown in parentheses.

\begin{tabular}{|c|c|c|c|c|c|c|c|}
\hline & Leaf & Bark & Fruit & Root & Flower & Seed & mean $(\Sigma)$ \\
\hline AGO-TC1 & $1.91(15)$ & $3.17(4)$ & $0.81(5)$ & - & $2.31(1)$ & - & $1.53(25)$ \\
\hline AGO-TC2 & $0.76(6)$ & $1.59(2)$ & $2.74(17)$ & - & - & $2.97(1)$ & $1.60(26)$ \\
\hline AGO-TC3 & $0.64(5)$ & - & $1.29(8)$ & $9.64(2)$ & - & - & $0.92(15)$ \\
\hline AGO-TC4 & $1.40(11)$ & - & $1.45(9)$ & - & - & - & $1.23(20)$ \\
\hline AGO-TC5 & $0.38(3)$ & $0.79(1)$ & - & - & - & - & 0.25 (4) \\
\hline AGO-TC6 & $0.13(1)$ & - & $0.16(1)$ & - & - & - & $0.12(2)$ \\
\hline AGO-TC7 & $0.13(1)$ & - & $0.48(3)$ & - & - & - & 0.25 (4) \\
\hline AGO-TC8 & $0.13(1)$ & - & $0.16(1)$ & - & - & - & $0.12(2)$ \\
\hline AGO-TC9 & $0.13(1)$ & $2.38(3)$ & - & - & - & - & 0.25 (4) \\
\hline AGO-TC10 & - & - & $0.32(2)$ & - & - & - & $0.12(2)$ \\
\hline AGO-TC11 & 0.13 (1) & - & $0.32(2)$ & - & - & - & 0.18 (3) \\
\hline AGO-TC12 & $0.13(1)$ & - & - & $4.82(1)$ & - & - & $0.12(2)$ \\
\hline AGO-TC13 & $0.25(2)$ & - & - & - & - & - & $0.12(2)$ \\
\hline$\Sigma$ & $6.12(48)$ & $7.93(10)$ & $7.73(48)$ & $14.46(3)$ & $2.31(1)$ & $2.97(1)$ & $6.81(111)$ \\
\hline DCL-TC1 & $0.38(3)$ & $0.79(1)$ & $0.48(3)$ & - & $2.31(1)$ & - & $0.49(8)$ \\
\hline DCL-TC2 & $0.25(2)$ & $1.59(2)$ & $0.32(2)$ & - & - & - & $\mathbf{0 . 3 7}(6)$ \\
\hline DCL-TC3 & $0.25(2)$ & $0.79(1)$ & $0.16(1)$ & - & - & - & 0.25 (4) \\
\hline$\Sigma$ & 0.88 (7) & 3.17 (4) & $0.96(6)$ & 0.00 & $2.31(1)$ & 0.00 & $1.10(18)$ \\
\hline HEN-TC1 & $0.13(1)$ & - & $0.48(3)$ & - & - & - & 0.25 (4) \\
\hline HEN-TC2 & $0.13(1)$ & $0.79(1)$ & - & - & - & - & $0.12(2)$ \\
\hline HEN-TC3 & $0.25(2)$ & - & - & - & - & - & $0.12(2)$ \\
\hline HEN-TC4 & - & - & $0.48(3)$ & - & - & - & 0.18 (3) \\
\hline HEN-TC5 & $0.25(2)$ & - & - & - & - & - & $0.12(2)$ \\
\hline$\Sigma$ & $0.76(6)$ & $0.79(1)$ & $0.96(6)$ & 0.00 & 0.00 & 0.00 & 0.80 (13) \\
\hline RdRP-TC1 & $1.40(11)$ & $1.59(2)$ & $1.77(11)$ & - & - & $2.97(1)$ & $1.54(25)$ \\
\hline RdRP-TC2 & $0.25(2)$ & - & $0.16(1)$ & - & - & - & 0.18 (3) \\
\hline RdRP-TC3 & $0.13(1)$ & $0.79(1)$ & $0.16(1)$ & - & - & - & 0.18 (3) \\
\hline RdRP-TC4 & $0.13(1)$ & - & $0.16(1)$ & - & - & - & $0.12(2)$ \\
\hline RdRP-TC5 & $0.13(1)$ & - & $0.32(2)$ & - & - & - & 0.18 (3) \\
\hline RdRP-TC6 & $0.25(2)$ & - & - & - & - & - & $0.12(2)$ \\
\hline$\Sigma$ & $2.29(18)$ & $2.38(3)$ & $2.57(16)$ & 0.00 & 0.00 & $2.97(1)$ & $\mathbf{2 . 3 3}(38)$ \\
\hline
\end{tabular}

${ }^{a}$ Libraries considered in this table: Leaf (CA-26-C1-002, CG-32-C1-003, CR-05-C1-100, CR-05-C1-102, CR-05-C1-103, CS-00-C1-100, CS-00-C1101, CS-00-C1-102, CS-00-C1-401, CS-00-C1-650, CS-13-C1-001, LT-33-C1-003, PT-11-C1-900, PT-11-C1-901; 78,516 reads); bark (CS-00-C2003, PT-11-C2-300, PT-11-C2-301; 12,610 reads); fruit (CR-05-C3-700, CR-05-C3-701, CR-05-C3-702, CS-00-C3-700, CS-00-C3-701, CS-00-C3702, CS-00-C3-703, CS-00-C3-704, CS-00-C3-705; 62,003 reads); root (CL-06-C4-500; 2,075 reads); flower (CS-00-C5-003; 4,330 reads); seed (PT-11-C9-005; 3,368 reads). Refer to Targon et al. (this issue) for explanation of library codes and total number of sequences in individual libraries.

reads, being by far the most transcribed group, with great activity in C. aurantifolia. Such a high expression of RdRP in C. aurantifolia is surprising since it is very susceptible to viruses such as CTV in contrast to a relatively low expression in P. trifoliata (given the number of reads in this species is not underrepresented), which implies that RdRP in citrus might not be required at high levels to guarantee virus resistance through RNA silencing. Notwithstanding, this enzyme was found to be a key component in antiviral de- fense mechanisms in plants. The RdRP from Nicotiana benthamiana accounted for the high virus susceptibility in this species when its gene was compared with orthologues of close relatives (Yang et al., 2004). Plants of $N$. benthamiana with reduced expression of RdRPs were shown to be more susceptible to viruses with even a greater effect at high temperatures (Qu et al., 2005; Schwach et al., 2005). It is noteworthy, however, that in C. aurantifolia, tristeza effects are more pronounced in cool climates, and 
Table 2 - Abundance of reads grouped by species into tentative consensus (TC) of genes involved in RNA silencing pathways in the CitEST database ${ }^{\mathrm{a}}$. Frequency is given per 10,000 transcripts and absolute numbers of valid reads are shown in parentheses.

\begin{tabular}{|c|c|c|c|c|c|c|c|c|}
\hline & $\begin{array}{c}\text { Citrus } \\
\text { aurantium }\end{array}$ & $\begin{array}{c}\text { Citrus } \\
\text { aurantifolia }\end{array}$ & $\begin{array}{c}\text { Citrus } \\
\text { limonia }\end{array}$ & $\begin{array}{c}\text { Citrus } \\
\text { reticulata }\end{array}$ & $\begin{array}{c}\text { Citrus } \\
\text { sinensis }\end{array}$ & $\begin{array}{c}\text { Citrus } \\
\text { latifolia }\end{array}$ & $\begin{array}{l}\text { Poncirus } \\
\text { trifoliata }\end{array}$ & mean $(\Sigma)$ \\
\hline AGO-TC1 & $1.68(1)$ & $3.02(2)$ & - & $1.01(4)$ & $1.27(10)$ & - & $3.28(8)$ & $1.53(25)$ \\
\hline AGO-TC2 & - & - & - & $2.03(8)$ & $1.90(15)$ & - & $1.23(3)$ & $1.60(26)$ \\
\hline AGO-TC3 & - & $1.51(1)$ & $9.64(2)$ & - & $1.39(11)$ & - & $0.41(1)$ & $0.92(15)$ \\
\hline AGO-TC4 & $5.04(3)$ & - & - & $1.27(5)$ & $1.39(11)$ & $1.82(1)$ & - & $1.23(20)$ \\
\hline AGO-TC5 & - & - & - & - & - & - & $1.64(4)$ & 0.25 (4) \\
\hline AGO-TC6 & - & - & - & $0.51(2)$ & - & - & - & $0.12(2)$ \\
\hline AGO-TC7 & - & - & - & - & $0.38(3)$ & - & $0.41(1)$ & 0.25 (4) \\
\hline AGO-TC8 & 1.68 (1) & - & - & - & $0.13(1)$ & - & - & $0.12(2)$ \\
\hline AGO-TC9 & - & - & - & $0.25(1)$ & - & - & $1.23(3)$ & 0.25 (4) \\
\hline AGO-TC10 & - & - & - & $0.51(2)$ & - & - & - & $\mathbf{0 . 1 2}(2)$ \\
\hline AGO-TC11 & - & - & - & $0.51(2)$ & $0.13(1)$ & - & - & 0.18 (3) \\
\hline AGO-TC12 & - & - & $4.82(1)$ & $0.25(1)$ & - & - & - & $0.12(2)$ \\
\hline AGO-TC13 & - & - & - & - & 0.13 (1) & $1.82(1)$ & - & $0.12(2)$ \\
\hline$\Sigma$ & 8.40 (5) & $4.53(3)$ & $14.46(3)$ & $6.34(25)$ & $6.72(53)$ & $3.64(2)$ & $8.20(20)$ & $6.81(111)$ \\
\hline DCL-TC1 & - & - & - & $0.25(1)$ & $0.63(5)$ & - & $0.82(2)$ & 0.49 (8) \\
\hline DCL-TC2 & $1.68(1)$ & - & - & $0.25(1)$ & $0.25(2)$ & - & $0.82(2)$ & $\mathbf{0 . 3 7}(6)$ \\
\hline DCL-TC3 & - & - & - & $0.25(1)$ & $0.38(3)$ & - & - & 0.25 (4) \\
\hline$\Sigma$ & $1.68(1)$ & 0.00 & 0.00 & $0.75(3)$ & $1.26(10)$ & 0.00 & $1.64(4)$ & $1.10(18)$ \\
\hline HEN-TC1 & - & - & - & - & $0.51(4)$ & - & - & 0.25 (4) \\
\hline HEN-TC2 & - & - & - & - & $0.13(1)$ & - & $0.41(1)$ & $0.12(2)$ \\
\hline HEN-TC3 & $1.68(1)$ & - & - & - & $0.13(1)$ & - & - & $0.12(2)$ \\
\hline HEN-TC4 & - & - & - & - & $0.38(3)$ & - & - & $0.18(3)$ \\
\hline HEN-TC5 & - & - & - & $0.25(1)$ & $0.13(1)$ & - & - & $0.12(2)$ \\
\hline$\Sigma$ & $1.68(1)$ & 0.00 & 0.00 & $0.25(1)$ & $1.28(10)$ & 0.00 & $0.41(1)$ & $\mathbf{0 . 8 0}(13)$ \\
\hline RdRP-TC1 & - & $6.04(4)$ & - & $1.52(6)$ & $1.52(12)$ & $1.82(1)$ & $0.82(2)$ & $1.54(25)$ \\
\hline RdRP-TC2 & - & $1.51(1)$ & - & $0.25(1)$ & $0.13(1)$ & - & - & 0.18 (3) \\
\hline RdRP-TC3 & - & - & - & - & $0.38(3)$ & - & - & 0.18 \\
\hline RdRP-TC4 & - & - & - & $0.25(1)$ & $0.13(1)$ & - & - & $\mathbf{0 . 1 2}(2)$ \\
\hline RdRP-TC5 & - & - & - & $0.76(3)$ & - & - & - & 0.18 (3) \\
\hline RdRP-TC6 & - & - & - & - & $0.25(2)$ & - & - & $0.12(2)$ \\
\hline$\Sigma$ & 0.00 & $7.55(5)$ & 0.00 & 2.78 & $2.41(19)$ & $1.82(1)$ & $\mathbf{0 . 8 2}(2)$ & $\mathbf{2 . 3 3}(38)$ \\
\hline
\end{tabular}

${ }^{a}$ Libraries considered in this table: C. aurantium (CA-26-C1-002; 5,950 reads); C. aurantifolia (CG-32-C1-003; 6,621 reads); C. limonia (CL-06-C4500; 2,075 reads); C. reticulata (CR-05-C1-100, CR-05-C1-102, CR-05-C1-103, CR-05-C3-700, CR-05-C3-701, CR-05-C3-702; 39,481 reads); C. sinensis (CS-00-C1-100, CS-00-C1-101, CS-00-C1-102, CS-00-C1-401, CS-00-C1-650, CS-13-C1-001, CS-00-C2-003, CS-00-C3-700, CS-00-C3701, CS-00-C3-702, CS-00-C3-703, CS-00-C3-704, CS-00-C3-705, CS-00-C5-003; 78,879 reads); C. latifolia (LT-33-C1-003; 5,484 reads); P. trifoliata (PT-11-C1-900, PT-11-C1-901, PT-11-C2-300, PT-11-C2-301, PT-11-C9-005; 24,412 reads). Refer to Targon et al. (this issue) for explanation of library codes and total number of sequences in individual libraries.

disease symptoms may be suppressed at temperatures above $30^{\circ} \mathrm{C}$ (Roistacher et al., 1974; Mathews et al., 1997).

A comprehensive transcriptional profiling of genes involved in RNA silencing pathways of citrus through the CitEST project was sometimes impaired by the low number of transcripts strongly resembling characterized genes in other species.
Some efforts have been made in characterizing RNA silencing in citrus, but no information has so far been reported on genetic components in its mechanisms. This work constitutes the first effort in finding the molecular players involved in RNA silencing in citrus species and exploring their relationship with virus resistance. Functional characterization of genes involved in RNA silencing present in resistant and susceptible species to viruses such as 
Table 3 - Similarity of citrus tentative consensus with Arabidopsis genes involved in PTGS pathways in each species. Only TCs with more than four reads per species were included.

\begin{tabular}{|c|c|c|c|c|c|c|c|c|}
\hline Species & $\begin{array}{l}\text { Tentative } \\
\text { consensus }\end{array}$ & $\begin{array}{l}\text { Number of } \\
\text { reads }\end{array}$ & Representative read & $\begin{array}{l}\text { Putative } \\
\text { orthologue }\end{array}$ & $\begin{array}{l}\text { Amino acid } \\
\text { identity }\end{array}$ & Coverage $^{a}$ & $\begin{array}{l}\text { Score } \\
\text { (bits) }\end{array}$ & $\mathrm{E}_{\text {value }}$ \\
\hline C. sinensis & AGO-TC1 & 10 & CS00-C5-003-060-D04-CT.F & \multirow{2}{*}{ AtAGO1 } & $86 \%$ & $626 / 1050$ & 1121 & 0.0 \\
\hline P. trifoliata & AGO-TC1 & 8 & PT11-C2-300-098-F11-CT.F & & $87 \%$ & $534 / 1050$ & 927 & 0.0 \\
\hline C. sinensis & AGO-TC2 & 15 & CS00-C3-703-002-E02-CT.F & \multirow{2}{*}{ AtAGO4 } & $69 \%$ & $555 / 924$ & 791 & 0.0 \\
\hline C. reticulata & AGO-TC2 & 8 & CR05-C1-100-088-A03-CT.F & & $70 \%$ & $698 / 924$ & 994 & 0.0 \\
\hline C. sinensis & AGO-TC3 & 11 & CS00-C3-701-102-H04-UV.F & AtAGO5 & $65 \%$ & $637 / 997$ & 819 & 0.0 \\
\hline C. sinensis & AGO-TC4 & 11 & CS00-C3-700-073-A10-CT.F & \multirow{2}{*}{ AtAGO4 } & $77 \%$ & $316 / 924$ & 516 & $5 \mathrm{e}^{-145}$ \\
\hline C. reticulata & AGO-TC4 & 5 & CR05-C3-702-091-E11-CT.F & & $76 \%$ & $217 / 924$ & 353 & $2 e^{-96}$ \\
\hline P. trifoliata & AGO-TC5 & 4 & PT11-C1-901-030-B06-CT.F & AtAGO9 & $68 \%$ & $147 / 896$ & 225 & $3 e^{-58}$ \\
\hline C. sinensis & DCL-TC1 & 5 & CS00-C3-701-079-E03-CT.F & AtDCL1 & $25 \%$ & $735 / 1909$ & 305 & $6 e^{-81}$ \\
\hline C. sinensis & HEN-TC1 & 4 & CS00-C3-705-022-A05-CT.F & AtHEN2 & $82 \%$ & $331 / 995$ & 486 & $7 e^{-136}$ \\
\hline C. sinensis & RdRP-TC1 & 12 & CS00-C2-003-076-C12-CT.F & \multirow{2}{*}{ AtSGS3 } & $62 \%$ & $384 / 625$ & 473 & $6 \mathrm{e}^{-132}$ \\
\hline C. reticulata & RdRP-TC1 & 6 & CR05-C3-700-047-F01-CT.F & & $54 \%$ & $604 / 625$ & 596 & $9 \mathrm{e}^{-169}$ \\
\hline
\end{tabular}

${ }^{\mathrm{a}}$ Number of amino acids of conceptually translated TC / number of amino acid of Arabidopsis orthologue protein.

CTV may promote the development of molecular tools to overcome one of the most important problems of the citrus industry.

\section{Acknowledgments}

The authors thank Dr. Maria Luisa P.N. Targon for constructing the cDNA libraries, Kleber M. Borges, Juliana M. de Souza, Sílvia O. Dorta and Carolina M. Rodrigues for technical assistance in sequencing the libraries, M.Sc. Marcelo Reis for the bioinformatic assistance, Dr. Marcos A. Machado for coordinating the CitEST Project, and CNPq/ Millennium Institute (62.0054/01-8) for financially supporting this work.

\section{References}

Baulcombe D (2004) RNA silencing in plants. Nature 431:356363.

Baumberger N and Baulcombe DC (2005) Arabidopsis ARGONAUTE1 is an RNA Slicer that selectively recruits microRNAs and short interfering RNAs. Proc Natl Acad Sci USA 102:11928-11933.

Benedito VA, Visser PB, Angenent GC and Krens FA (2004) The potential of virus-induced gene silencing for speeding up functional characterization of plant genes. Genet Mol Res 3:323-341.

Bennetzen JL (2000) Transposable element contributions to plant gene and genome evolution. Plant Mol Biol 42:251-269.

Carmell MA, Xuan Z, Zhang MQ and Hannon GJ (2002) The Argonaute family: Tentacles that reach into RNAi, developmental control, stem cell maintenance, and tumorigenesis. Genes Dev 16:2733-2742.

Chandler VL and Vaucheret H (2001) Gene activation and gene silencing. Plant Physiol 125:145-148.

Chen X, Liu J, Cheng Y and Jia D (2002) HEN1 functions pleiotropically in Arabidopsis development and acts in $\mathrm{C}$ function in the flower. Development 129:1085-1094.
Domínguez A, Fagoaga C, Navarro L, Moreno P and Peña LB (2002) Regeneration of transgenic citrus plants under nonselective conditions results in high-frequency recovery of plants with silenced transgenes. Mol Genet Genomics 267:544-556.

Fagard M, Boutet S, Morel JB, Bellini C and Vaucheret H (2000) AGO1, QDE-2, and RDE-1 are related proteins required for post-transcriptional gene silencing in plants, quelling in fungi, and RNA interference in animals. Proc Natl Acad Sci USA 97:11650-11654.

Fagoaga C, López C, Mendoza AH, Moreno P, Navarro L, Flores $R$ and Peña L (2006) Post-transcriptional gene silencing of the p23 silencing suppressor of Citrus tristeza virus confers resistance to the virus in transgenic Mexican lime. Plant Mol Biol 60:153-165.

Gasciolli V, Mallory AC, Bartel DP and Vaucheret H (2005) Partially redundant functions of Arabidopsis DICER-like enzymes and a role for DCL4 in producing trans-acting siRNAs. Curr Biol 15:1494-1500.

Hily J-M, Scorza R, Webb K and Ravelonandro M (2005) Accumulation of the long class of siRNAs is associated with resistance to Plum pox virus in a transgenic woody perennial plum tree. Mol Plant-Microbe Interact 18:794-799.

Huang X and Madan A (1999) CAP3: A DNA sequence assembly program. Genome Res 9:868-877.

Hunter C, Sun H and Poethig RS (2003) The Arabidopsis heterochronic gene ZIPPY is an ARGONAUTE family member. Curr Biol 13:1734-1739.

Kidner CA and Martienssen SA (2005) The developmental role of microRNA in plants. Curr Opin Plant Biol 8:38-44.

Lu R, Folimonov A, Shintaku M, Li W-X, Falk BW, Dawson WO and Ding S-W (2004) Three distinct suppressors of RNA silencing encoded by a $20-\mathrm{kb}$ viral RNA genome. Proc Natl Acad Sci USA 101:15742-15747.

Lynn K, Fernandez A, Aida M, Sedbrook J, Tasaka M, Masson P and Barton MK (1999) The PINHEAD/ZWILLE gene acts pleiotropically in Arabidopsis development and has overlapping functions with the ARGONAUTE1 gene. Development 126:469-481. 
Mathews DM, Riley K and Dodds JA (1997) Comparison of detection methods for Citrus tristeza virus in field trees during months of nonoptimal titer. Plant Dis 81:525-529.

Mette MF, Aufsatz W, van der Winden J, Matzke MA and Matzke AJ (2000) Transcriptional silencing and promoter methylation triggered by double-stranded RNA. EMBO J 2:51945201.

Morel JB, Godon C, Mourrain P, Beclin C, Boutet S, Feuerbach F, Proux F and Vaucheret H (2002) Fertile hypomorphic ARGONAUTE (agol) mutants impaired in post-transcriptional gene silencing and virus resistance. Plant Cell 14:629-639.

Mourrain P, Beclin C, Elmayan T, Feuerbach F, Godon C, Morel JB, Jouette D, Lacombe AM, Nikic S, Picault N, et al. (2000) Arabidopsis $S G S 2$ and $S G S 3$ genes are required for posttranscriptional gene silencing and natural virus resistance. Cell 101:533-542.

Moussian B, Schoof H, Haecker A, Jurgens G and Laux T (1998) Role of the ZWILLE gene in the regulation of central shoot meristem cell fate during Arabidopsis embryogenesis. EMBO J 17:1799-1809.

Qi Y and Hannon GJ (2005) Uncovering RNAi mechanisms in plants: Biochemistry enters the foray. FEBS Lett 579:58995903.

Qu F and Morris TJ (2005) Suppressors of RNA silencing encoded by plant viruses and their role in viral infections. FEBS Lett 579:5958-5964.

Qu F, Ye X, Hou G, Sato S, Clemente TE and Morris TJ (2005) RDR6 has a broad-spectrum but temperature-dependent antiviral defense role in Nicotiana benthamiana. J Virol 79:15209-15217.

Roistacher CN, Blue RL, Nauer EM and Calavan EC (1974) Suppression of tristeza virus symptoms in Mexican lime seedlings grown at warm temperatures. Plant Dis Rep 58:757760.

Sassaki FT, Campos-Pereira T and Maia IG (2005) The posttranscriptional gene silencing pathway in Eucalyptus. Genet Mol Biol 28:496-500.

Schwach F, Vaistij FE, Jones L and Baulcombe DC (2005) An RNA-dependent RNA polymerase prevents meristem invasion by Potato virus $X$ and is required for the activity but not the production of a systemic silencing signal. Plant Physiol 138:1842-1852.

Scorza R, Callahan A, Levy L, Damsteegt V, Webb K and Ravelonandro M (2001) Post-transcriptional gene silencing in Plum pox virus resistant transgenic European plum containing the plum pox potyvirus coat protein gene. Transgenic Res 10:201-209.

Vaucheret H, Vazquez F, Crete P and Bartel DP (2004) The action of ARGONAUTE1 in the miRNA pathway and its regulation by the miRNA pathway are crucial for plant development. Genes Dev 18:1187-1197.

Vazquez F, Vaucheret H, Rajagopalan R, Lepers C, Gasciolli V, Mallory AC, Hilbert JL, Bartel DP and Crete P (2004) Endogenous trans-acting siRNAs regulate the accumulation of Arabidopsis mRNAs. Mol Cell 16:69-79.

Waterhouse PM, Wang MB and Lough T (2001) Gene silencing as an adaptative defense against viruses. Nature 411:834842.

Yang S-J, Carter SA, Cole AB, Cheng N-H and Nelson RS (2004) A natural variant of a host RNA-dependent RNA polymerase is associated with increased susceptibility to viruses by Nicotiana benthamiana. Proc Natl Acad Sci USA 101:6297-6302.

Yang Z, Ebright YW, Yu B and Chen X (2006) HEN1 recognizes 21-24 nt small RNA duplexes and deposits a methyl group onto the 2' $\mathrm{OH}$ of the 3' terminal nucleotide. Nucleic Acids Res 34:667-675.

Zamore PD (2002) Ancient pathways programmed by small RNAs. Science 296:1265-1269.

Zilberman D, Cao X and Jacobsen SE (2003) ARGONAUTE4 control of locus-specific siRNA accumulation and DNA and histone methylation. Science 299:716-719.

Zilberman D, Cao X, Johansen LK, Xie Z, Carrington JC and Jacobsen SE (2004) Role of Arabidopsis ARGONAUTE4 in RNA-directed DNA methylation triggered by inverted repeats. Curr Biol 14:1214-1220.

\section{Internet Resources}

CitEST database: http://citest.centrodecitricultura.br (November 10, 2006).

Associate Editor: Ivan de Godoy Maia 